\title{
7
}

\section{The role played by reconciliation in social reconstruction in Bougainville}

Joanne Wallis

In his final editorial in The International Journal of Transitional Justice, Harvey Weinstein lamented that, as a field, 'we have not been successful at promoting a research agenda that values the study of effectiveness' (Weinstein 2011, 1). Instead, much of the literature has assumed that transitional justice plays a positive role in the social reconstruction of conflict-affected societies. Much of the literature also assumes (either explicitly or implicitly) that this social reconstruction should be guided by liberalism, grounded in individual human rights protected by the rule of law. A nascent literature has evaluated the effect of truth commissions and criminal trials, particularly on efforts to establish respect for human rights. There has been little similar research to evaluate the effectiveness of local reconciliation practices, rather than prosecutions, and little research that challenges the assumption that social reconstruction should be guided by liberalism. My chapter evaluates the role played by local reconciliation practices in social reconstruction in Bougainville, including an analysis of what social reconstruction means in the Bougainville context. Local reconciliation practices are taken to mean local sociopolitical practices aimed at building and healing relationships so that formerly conflictual parties can live together peacefully. 
Bougainville is an autonomous region of Papua New Guinea that endured a conflict between 1989 and 1997. Bougainville experienced only 'light' international intervention to end the war; near neighbours Australia and New Zealand provided small, unarmed truce and peace monitoring teams and the United Nations a minute observer mission (Regan 2010a). Bougainvillean political leaders opted to achieve peace by prioritising local reconciliation practices and by offering amnesties from prosecution, and pardons for those already prosecuted, for crimes (including human rights abuses) committed during the conflict as an incentive to former combatants to participate in reconciliation and weapons disposal. In the short term this approach appears to have worked; the conflict ended in 1997 and in 2001 a comprehensive political settlement, outlined in the Bougainville Peace Agreement, granted Bougainville extensive political autonomy and the right to vote on its political future (with the option of independence) between 2015 and 2020. A constitution-making process was undertaken between 2002 and 2004, and by 2005 Bougainvilleans had established the Autonomous Bougainville Government (ABG) (Wallis 2014). There has not been a major outbreak of violence since.

In this chapter, I consider some of the possible long-term consequences of the approach to reconciliation adopted in Bougainville for social reconstruction. As I focus on what social reconstruction means in Bougainville, I am particularly interested in the potential gap between, on the one hand, the liberal assumptions upon which much of the transitional justice literature is based and, on the other hand, the local context.

Internationally, civil society has been at the forefront of debates about how transitional justice should be conducted and the ends it should pursue. Encouraged by this international discourse, in Bougainville more formalised civil society organisations (CSOs) have tended to favour liberal approaches. For example, the Bougainville Human Rights Committee has argued that the lack of a formal transitional justice mechanism has created the impression that 'anyone can choose to perpetrate a crime with impunity' (Bougainville Human Rights Committee 2011). Consequently, these CSOs have called for a formal transitional justice mechanism, constituting either a truth and reconciliation commission or criminal trials, or combination of the two, to help address this growing culture of impunity and to establish the liberal principles of the rule of law and respect for human rights. In contrast, grassroots CSOs have tended to favour reconciliation grounded in local sociopolitical practices, not necessarily underpinned by liberal assumptions. 
I begin by considering the literature relating to evaluating the impact of transitional justice, including local reconciliation practices. Building on that literature, I identify two criteria to evaluate the impact of reconciliation on the social reconstruction of a conflict-affected society: governance and justice. I then describe the conflict in Bougainville and the reconciliation that occurred. I then evaluate the role that reconciliation has played in social reconstruction in Bougainville against the two criteria and conclude that, while it has helped to create an environment in which relatively legitimate and effective institutions of governance have been created, it has undermined attempts to achieve justice by cultivating a culture of impunity. My analysis also highlights how attempts to evaluate the effect of reconciliation in Bougainville need to extend beyond an analysis of liberal principles and practices to incorporate the local sociopolitical principles and practices that continue to determine the nature of everyday life for many Bougainvilleans.

\section{Evaluating the impact of transitional justice and reconciliation}

Some form of transitional justice is now included in most peace processes, and has 'come to dominate debates on the intersection between democratization, human rights protections, and state reconstruction after conflict' (McEvoy 2007, 412). Transitional justice refers to the 'practices, mechanisms and concerns that arise following a period of conflict, civil strife, or repression, and that are aimed directly at confronting past violations of human rights and humanitarian law' (Roht-Arriaza 2006, 2). The most prominent mechanisms are truth commissions and criminal trials, but transitional justice can also include local reconciliation practices, reparations, memorialisation, and transitional legal and institutional reforms such as vetting and lustration (Thoms, Ron and Paris 2010). Truth commissions are temporary, usually state-sanctioned, bodies that investigate 'a pattern of abuses over a period of time, rather than a specific event' (Hayner 2001, 14) in order to 'supply narrative, rather than forensic, accounts of the past' (Thoms, Ron and Paris 2010, 334). Criminal trials aim to achieve 'truth, deterrence, punishment, reconciliation and promotion of the rule of law' (Thoms, Ron and Paris 2010, 333). They are premised on the belief that criminal punishment serves victims' needs by offering a sense of justice, catharsis and that 'their grievances have been addressed and can hopefully be put to rest' (Kritz 1996, 128). 
I focus on reconciliation guided by local sociopolitical practices, which involves achieving 'negative peace' - that is, the cessation of violence and the (re)establishment of relationships that permit the coexistence of formerly hostile individuals or groups (Galtung 1990). It also aims to achieve 'positive peace', whereby it addresses 'conflictual and fractured relationships' in order to build and heal relationships (Hamber and Kelly 2004, 3; Lederach 1997). Reconciliation may take place at the interpersonal level, whereby relationships are restored between individual perpetrators and victims. It may also occur at the political level, to address wrongs committed by agents of the state, members of the opposition, separatist movements, militias or warring factions in the name of the organisation or cause with which they are affiliated, to establish societal and political processes that prevent a reversion to conflict (Philpott 2006). It is possible to achieve interpersonal reconciliation without political reconciliation, and vice versa, and the two may happen at the expense of each other. However, the two are interconnected, as rebuilding interpersonal relationships is often the key to facilitating broader political reconciliation between opposing individuals and groups. As unresolved resentments, underlying tensions and simmering hostilities have the potential to generate further conflict (Biggar 2003; Collier and Hoeffler 2004), it is claimed that reconciliation can be perceived as a panacea for past wrongs and as a form of social inoculation against a future return to violence (Long and Brecke 2003,13). As noted, reconciliation is usually guided by local sociopolitical practices, which often prioritise 'restorative' over 'retributive' justice (Braithwaite 2003).

Thoms, Ron and Paris find that 'reliable empirical knowledge on the state-level impact of TJ [transitional justice] is still limited' (Thoms, Ron and Paris 2010,331). Weinstein argues that the literature appears to have been reluctant to evaluate the impact of transitional justice because " it is too soon" to look at what transitional justice actually accomplishes in the social reconstruction of a country' (Weinstein 2011, 1). This reluctance also reflects the implicit liberal assumption that criminal accountability is common sense and therefore does not need to be questioned.

There is also little agreement regarding what criteria should be used to evaluate the outcomes of transitional justice (Brahm 2007). While most scholars would agree that these outcomes should be peace and justice, there is no consensus regarding what these terms mean. Brahm has suggested two ways to evaluate the impacts of truth commissions: first, their effect on 'subsequent human rights practices'; and second, their 
effect on 'democratic development'. Thoms, Ron and Paris have suggested six criteria for evaluating the effects of trials and truth commissions: '(1) state respect for personal integrity rights ...; (2) levels of political violence; (3) adherence to the rule of law; (4) democratization; (5) popular perceptions of regime legitimacy; and (6) a political culture of human rights and diversity' (Thoms, Ron and Paris 2010, 331). Therefore, these scholars implicitly assume that the outcomes of transitional justice should be grounded in liberalism.

The liberal assumptions that have guided much of the transitional justice literature reflect the fact that much of the literature has its roots in liberal human rights discourse, with transitional justice mechanisms such as criminal trials and truth commissions seen as a way to combat impunity for human rights abuses. However, as illustrated below, universalist assumptions regarding the desirability or appropriateness of liberalism, particularly liberal human rights protections, do not necessarily hold in all conflict-affected contexts, nor do the highly technocratic, decontextualised and depoliticising approaches to transitional justice (such as truth commissions and trials) that they tend to generate.

With these caveats in mind, I identify two criteria as critical to evaluating the impact of reconciliation on the social reconstruction of a conflictaffected society: the establishment of effective and legitimate governance mechanisms, that is, mechanisms to manage the exercise of political power and provide opportunities for the people to influence the way that power is exercised; and the achievement of justice, that is, mechanisms aimed at eliminating arbitrary distinctions and establishing 'the structure of a practice of a proper balance between competing claims' (Rawls 1958, 165). Although these definitions are drawn from liberal theory, they are intended to be sufficiently broad to capture differing understandings, including those grounded in local sociopolitical practices, of what these governance mechanisms should look like and what a proper balance between competing claims involves.

While liberalism holds that governance should be democratic, to recognise the 'intrinsic equality' and 'personal autonomy' of individuals (Dahl 1989, 86), the critical peacebuilding literature has increasingly recognised that, to be effective and legitimate, governance mechanisms may need to combine both liberal and local sociopolitical principles in a process described as 'hybridity' (Richmond 2009). Similarly, liberalism holds that justice should be guided by the principle of the 'rule of law', 
which is based on the idea that the law must be universally and consistently applied - including to the government - by a formal regulatory system in which there is a clear hierarchy of law (Tamanaha 2004). The protection of human rights is linked to the rule of law, since human rights protections seek to ensure that the freedom and equality of individuals is protected against untrammelled majority rule and are usually enumerated in law and enforced via the courts. However, critical peacebuilding scholars are increasingly arguing that to be perceived as both effective and legitimate, justice may involve a range of both liberal and local mechanisms, and human rights protections may need to protect both group and individual rights (Boege, Brown and Clements 2009).

As noted, there is a nascent literature that has evaluated the effects of truth commissions and criminal trials, used individually or in conjunction with each other, on the social reconstruction of conflict-affected societies (Pham and Vinck 2007; Thoms, Ron and Paris 2010). Reflecting their basis in liberalism, one study that focused on criminal trials concluded that prosecutions for human rights violations led to subsequent improvements in human rights protections, and had a deterrent effect both in the society in question and beyond (Kim and Sikkink 2010). Another study concluded that claims that criminal trials 'threaten democracy, increase human rights violations, and exacerbate conflict' were not supported by empirical evidence from Latin America (Sikkink and Booth Walling 2007). Another found there is a 'justice balance', whereby truth commissions are unable to promote stability and accountability on their own, but can contribute to improvements in human rights protections when they complement and enhance amnesties and prosecutions (Olsen et al. 2010). Other studies have concluded that a failure to conduct criminal trials can generate a culture of impunity. A study of Guatemala found that a failure to prosecute violent crimes committed against women during the conflict, when the army was trained in the rape and torture of women, has contributed to subsequent impunity for these crimes and consequently to rising levels of murder of women in post-conflict Guatemala (Sanford and Lincoln 2011).

Studies of truth commissions on their own have reached more measured conclusions. One found that truth commissions can have a 'direct political impact' through the implementation of their recommendations, an 'indirect political impact' through their role in mobilising civil society, a 'positive judicial impact' by contributing to human rights accountability, and a 'negative judicial impact' by promoting impunity (Bakiner 2014, 26, 27). 
A study of Liberia's Truth and Reconciliation Commission concluded that it has contributed to a perception of impunity because political elites, many of whom perpetrated human rights abuses during the conflict, have undermined its implementation, including its recommendations for criminal trials (Weah 2012).

There has been little substantive effort to evaluate the effect of local reconciliation practices on the social reconstruction of conflict-affected societies. As reconciliation is often presented as a locally driven alternative to the formal transitional justice models of truth commissions and criminal trials, the literature has tended to overlook the causal relationship between reconciliation and the social reconstruction of conflict-affected societies. One of the challenges of conducting a comparative evaluation of the effect of reconciliation across cases is that, while there are common understandings of what constitutes truth commissions and criminal trials, reconciliation is usually guided by local sociopolitical practices and therefore varies across societies. In addition, it is usually more straightforward to identify when truth commissions and criminal trials have concluded, and what their outcomes are, at least in terms of what 'truth' they uncover and prosecutions they achieve. In contrast, it is questionable whether reconciliation has an end date or a final outcome; it may be more accurate to see reconciliation as an open, ongoing process. Weinstein has asked whether 'closure [is] a valid concept and is the idea relevant across culture? Is resolution possible as an end-state?' $(2011,5)$. Opotow has similarly argued that 'labelling a conflict - particularly a violent, protracted, and deadly conflict - as reconciled can be dangerous' as it can 'raise hopes and expectations of victims, blunt bystander vigilance, and allow impunity to flourish' (Opotow 2001, 166). Moreover, if a more nuanced, contextspecific approach to evaluating social reconstruction is adopted this is also likely to vary across cases, making comparison difficult.

One emerging consensus in the transitional justice literature informed by liberalism is that the increasing use of amnesties to facilitate reconciliation may have enhanced the risk of creating a culture of impunity. Indeed, one study that evaluated the consequences of reconciliation for social justice concluded that using amnesties to promote reconciliation can 'be particularly disheartening when it institutionalizes and legitimizes impunity' (Opotow 2001, 161). A culture of impunity - that is, 'exemption from accountability, penalty, punishment, or legal sanction for perpetrators of illegal acts' (Opotow 2001, 149; Afflito 2000; McSherry and Molina Mejia 1992; Penrose 1999) - is seen to undermine efforts to 
establish the rule of law and respect for human rights. While much of the literature is implicitly guided by the liberal assumption that transitional justice should pursue criminal accountability, and consequently that impunity refers to avoiding criminal sanction, a culture of impunity can also emerge when perpetrators are perceived to have avoided participating (or participating meaningfully) in reconciliation or sanctions dictated by local justice practices. Indeed, because local justice practices remain influential in Bougainville, many people who committed crimes or human rights abuses during the conflict have been subject to customary sanctions even though they have avoided criminal sanction.

Amnesties can go to the heart of the peace versus justice dilemma: on the one hand, amnesties are seen by some as a necessary sacrifice to achieve peace, by encouraging antagonistic groups to surrender their weapons and participate in reconciliation; on the other hand, others argue that meaningful peace cannot be achieved without justice (Mallinder 2007). In some cases, democratic governments have overcome amnesty laws to allow for criminal trials for past human rights violations (Lessa et al. 2014). When this does not occur, studies have concluded that impunity can be conferred on perpetrators "under the guise of "reconciliation", as occurred in Guatemala (Molina Mejia 1999, 61), or that impunity was called reconciliation' in Chile (Paz 1999, 25). While amnesties and other provisions that facilitate impunity might be seen as necessary to end conflict, reconciliation predicated on impunity may be short-sighted and trade 'short-term potential gains for a long-term continuation of impunity' (Roht-Arriaza 1996, 99). Despite this, advocates have argued that amnesties 'accompanied by traditional community-based justice mechanisms can co-exist with international prosecutions for those who are "most responsible"' for crimes. Amnesties can also be used in conjunction with restorative justice mechanisms to encourage perpetrators to participate without inculpating themselves', as occurred in South Africa (Mallinder 2007, 221). In these cases, amnesties could be granted on the condition that perpetrators comply with the penalties imposed by the restorative justice mechanism, such as public identification and apology, community service or financial compensation.

Since the late 1990s, the United Nations has maintained that amnesties that prevent prosecutions for war crimes, genocide, crimes against humanity and other gross violations of human rights are 'inconsistent' with states' obligations under the international human rights treaties, United Nations Policy and emerging principles of customary law 
(OHCHR 2006). The United Nations' Basic Principles and Guidelines on the Right to a Remedy holds that victims have the right to 'equal and effective justice', 'adequate, effective and prompt reparation for harm suffered' and 'access to relevant information concerning violations and reparation mechanisms' (United Nations General Assembly 2005). Indeed, the International Criminal Court and ad hoc criminal tribunals established by the United Nations for Rwanda and the former Yugoslavia could disregard domestic amnesty laws and prosecute perpetrators of human rights abuses. States may also be legally obliged to prosecute under the Genocide Convention, Convention against Torture and Other Cruel, Inhuman or Degrading Treatment or Punishment and the Geneva Conventions (Orentlicher 1991).

Therefore, it has been argued that a "justice cascade has emerged, along with global human rights and accountability norms, the institutionalization and enforcement of those norms and the demand for the implementation of those norms by domestic and international human rights advocates' (Lessa et al. 2014, 83). That is, at the international level transitional justice has been legalised and judicialised, and consequently accountability achieved via criminal trials is seen as the most legitimate means of achieving justice after conflict. Reflecting this justice cascade, there is increasing demand by international CSOs for criminal trials to overcome perceived impunity (Becker 2003; Loveman 1998). This demand has trickled down to CSOs in conflict-affected societies, in part because international CSOs have promoted these ideas, including via their funding. These interventions can have a distorting effect on CSOs in conflict-affected societies, as they can empower organisations willing (or able) to speak in the internationalised language of transitional justice and human rights, which usually consist of urban elites, while marginalising groups that are more focused on local sociopolitical practices, which usually operate at the grassroots level. As noted, conceptions of transitional justice guided by liberalism can also become highly technocratic and depoliticising, and with their relatively narrow focus on human rights obscure wider conversations about power, governance and justice. By arguing for criminal trials, which are usually conducted by the state against individual perpetrators in relation to individual victims, these conceptions can also reinforce both the state and the liberal emphasis on individualism.

In much of the transitional justice literature, 'civil society' is taken to include 'nongovernmental organizations (NGOs), individual activists and other social groups, including human rights, victim, student, 
neighbourhood and trade union organizations, that play an active role in generating conditions necessary to push governments to reckon with past atrocities' (Lessa et al. 2014, 76). This characterisation is also shaped by liberalism and focuses on the public sphere - that is, an arena of association that is concerned with state affairs, but which is not part of the formal state structure (Habermas 1996). The focus on the public sphere raises questions over its adequacy in contexts where there is an unclear line between the public and private spheres, and where CSOs are not formally part of the state structure, yet cannot be easily separated from the state, or from the private sphere. Moreover, while much of the transitional justice literature (and indeed the broader literature on civil society) assumes that $\mathrm{CSO}$ are secular, this definition raises questions regarding its relevance in contexts where much of what would be classified as civil society is faith based. These questions grow louder in contexts, such as the Pacific Islands, where states themselves are only shallowly rooted in society and many people do not have a strong understanding of themselves as citizens of a state. This highlights how much of the transitional justice literature perpetuates liberal assumptions regarding the relevance and legitimacy of states as actors capable of facilitating or complying with formal transitional justice mechanisms.

\section{Conflict and reconciliation in Bougainville}

The Bougainville conflict was complex; while it is often described as a struggle between secessionist Bougainvilleans and the Papua New Guinea Government, it was also an internal conflict between - and within - pro- and anti-secessionist Bougainvillean elements, often based on localised concerns or criminal activity (Regan 2001; Boege 2009). Both Bougainvillean and international CSOs documented the many human rights abuses committed during the crisis. ${ }^{1}$

Civil society, broadly defined, in Bougainville is dominated by faith-based and women's organisations, although there is significant overlap between the two. The most prominent CSOs are centred on the three main churches (Catholic, Methodist and Seventh Day Adventist). Both during and since the conflict, Bougainvillean political leaders have sought counsel from

1 During the crisis, women's leader Marilyn Havini kept a record of human rights abuses that had been committed. Amnesty International also recorded abuses that occurred during the early stages of the crisis (Havini 1995, 1996; Amnesty International 1990). 
the heads of the churches, and the current Bougainville president, John Momis, is a former Catholic priest who retains strong ties to the church. Church leaders play an important role in shaping public opinion via their sermons and, increasingly, via their ties to (or at least endorsements of) political candidates (interview with an ABG official, 22 January 2011). The fact that many schools and health facilities are run by churches, and some are jointly funded by the church and the autonomous government, also provides the churches with considerable political weight (interview with an international academic, 8 January 2010; Masono 2006). Indeed, one public servant noted that the churches are 'traditionally seen as the right hand of government in terms of development' and consequently the autonomous government pays them 'tithes' (interview with an ABG official, 22 January 2011). Their weight has been enhanced by the fact that they have begun to engage in commercial projects such as real estate, hotels, shipping, agriculture and plantations. The influence of the churches at the local level has also been enhanced by the fact that they have syncretised or 'interwoven' their beliefs and practices with Bougainvillean culture 'so that they combine custom and Christianity' (Boege and Garasu 2004, 573).

Women's CSOs are also active, including the secular Leitana Nehan Women's Development Agency, Bougainville Women for Peace and Freedom, and Bougainville Women's Federation and the faith-based Bougainville Inter-Church Women's Forum (Hakena, Nines and Jenkins 2006; Sirivi and Havini 2004). While some women's groups are nominally secular, the women involved are often church leaders and their platforms are influenced by faith-based norms. Many of these groups date back to the conflict, when they were formed to promote reconciliation (interview with a women's leader, 25 January 2011; interview with a women's leader, 2 February 2010). They then played an important role in promoting awareness of the peace process, and since autonomy have campaigned aggressively to promote women's rights and development.

According to local Bougainvillean sociopolitical practices, dispute resolution and societal cohesion follow a restorative justice approach guided by the principle of 'balanced reciprocity', which requires reconciliation - that is, truth-telling and forgiveness - and compensation to restore balance within the community (Regan 2005, 420). Consequently, local reconciliation practices have been prioritised, as they are seen as offering a way to 'reunite us to be one people again' and of ensuring that 'whatever happened during the war is not passed on to the next generation' 
(Sister Lorraine Garrasu speaking in Thompson 2002). Utilising local customary practices to effect reconciliation means that it is irrevocable. Whatever we decide by these traditional means, will be guaranteed by society' (Jon Boboso speaking in Thompson 2002). Under the influence of faith-based CSOs, reconciliation ceremonies have combined local practices with Christian principles (Boege 2012). This combination has enhanced their legitimacy, and these reconciliation efforts have done more to consolidate popular commitment to peace than any other aspect of the process' (Regan 2001, 15).

Pragmatic decisions made during the peace process have limited the scope for Bougainvillean CSOs to advocate for a formal transitional justice mechanism. In order for the Bougainville parties to the conflict to agree to a common position on which to negotiate peace with the Papua New Guinea Government, the Australian and New Zealand governments facilitated a number of peace talks, which first resulted in an interim ceasefire. To make that ceasefire permanent, the Bougainville parties and Papua New Guinea Government agreed to offer amnesties and pardons to persons involved in offences related to the conflict. This offer was legally enshrined in the Bougainville Peace Agreement 2001, and subsequently in the Papua New Guinea Constitution. Granting amnesties and pardons was seen as necessary in order to encourage combatants to participate in the weapons disposal process created by the peace agreement, particularly as the agreement had left the political status of Bougainville open, with the region granted extensive autonomy and the possibility of independence determined by a later referendum.

To prepare Bougainville for the referendum, in 2008 the autonomous government developed a taskforce to support local reconciliation practices. Local-level reconciliation ceremonies had been ongoing throughout the conflict, had flourished during the peace process and have continued in the period since. Although they were not formally linked to the weapons disposal process, they helped to create an environment in which the process was deemed sufficiently advanced that the United Nations Observer Mission declared it completed in May 2005. However, many weapons remained in the community after autonomy. Consequently, in 2009 the autonomous government created a Ministry of Peace, Reconciliation and Weapons Disposal (later replaced by the Department of Bougainville Peace Agreement Implementation) and in 2012 it adopted a Peace, Security and Weapons Disposal Strategy. In 2013, Australia also began to fund the Bougainville Peace Building Strategy to encourage reconciliation and 
weapons disposal. In 2017, the autonomous government and Papua New Guinea Government created an independent Bougainville Referendum Commission to conduct the referendum.

\section{Evaluating the effects of reconciliation in Bougainville}

As described, I use two criteria to evaluate the effects of reconciliation on social reconstruction in Bougainville: governance and justice.

\section{Governance}

Reconciliation conducted before, during and since the peace process created space for a highly participatory constitution-making process during which Bougainvilleans negotiated the design of their governance institutions (Wallis 2014). They agreed that the Bougainville autonomous government would be a liberal institution, which includes a democratically elected legislature (the House of Representatives) and executive (the Bougainville President and Executive Council).

Bougainvilleans appear to have embraced liberal democracy at the regional level, indicated by high levels of electoral participation (Regan 2009; Commonwealth Secretariat and PIF 2005). The voting strategies utilised by Bougainvilleans also illustrate the growing influence of liberal democracy, as there is evidence that voters have developed political sophistication by gradually shifting their focus away from the issues of the conflict and towards the performance of the autonomous government, appearing to prioritise immediate concerns of local conflict, progress in the implementation of the Bougainville Peace Agreement and improvements in Bougainville's development (Regan 2010b). Evidence of growing acceptance of liberal democracy as a method of governance at the regional level is also provided by the fact that there has been no significant violence during, or after, autonomous government elections. Independent electoral observers have concluded that the elections were 'democratic, transparent, inclusive and credible' (Commonwealth Secretariat and PIFS 2010). One member of the autonomous government argued that this demonstrates the 'maturity' of Bougainvilleans in accepting the democratic process and moving away from conflict (Nisira 2010). 
However, to look only at formal governance institutions presents an incomplete picture of social reconstruction in Bougainville. During the constitution-making process, Bougainvilleans agreed that at the village level local sociopolitical institutions should continue to perform much everyday governance. These local institutions consist of Village Assemblies at the level of the census village (of which there are approximately 600), which feed up into Councils of Elders (of which there are approximately 90). The councils have been the 'most effective governance institutions' below the autonomous government (Boege 2008, 28), as they connect the 'modern, formal' autonomous government with the traditional Village Assemblies (interview with a former member of the ABG, 2 November 2010) that continue to regulate the lives of the over 90 per cent of Bougainvilleans who live in rural areas (Finnroad 2008). The term 'Village Assembly' is used to describe these traditional systems of government, which are the (often loosely organised) methods by which traditional chiefs consult their people and perform their traditional administrative and dispute resolution role (Council of Elders Act, sections 9-10; interview with an ABG official, 22 January 2011). The Village Assemblies are also said to provide a 'pivotal link between the Council of Elders and the communities - and vice versa' (Sasa 2013, 53).

Wider acceptance of the role of liberal democracy in governance among ordinary Bougainvilleans is more limited. The Councils of Elders are only nominally democratic: to achieve balance between the liberal emphasis on democratic elections and local emphasis on customary authority, councils are 'mainly elective', but must also 'recognize the traditional role in governance of traditional chiefs and other traditional leaders' (ABG Constitution, section 49). In practice, these elections are more like 'selections', as there is no competition of candidates, with council members chosen in a consensual manner, reflecting local practices (Boege 2013, 19).

Therefore, to evaluate the role that reconciliation has played in social reconstruction in Bougainville it is necessary to examine both the role of liberal democratic and of local sociopolitical governance institutions. This highlights how a study of Bougainville guided solely by the transitional justice literature focused on the importance of liberal democracy would miss the important role that local sociopolitical practices play in governance. Applying a more nuanced analysis to Bougainville suggests that reconciliation has helped to establish both effective and legitimate liberal and local governance institutions, as it has created an environment 
in which Bougainvilleans have been able to negotiate and agree to the design of those institutions, and in which they have been able to peacefully work through them to govern Bougainville.

\section{Justice}

As with governance, there is a combination of both liberal and local sociopolitical justice mechanisms in Bougainville. At the regional level, the Bougainville Police Service seeks to enforce law and order, and the courts seek to uphold the rule of law. As a significant amount of court infrastructure was lost and many court files were destroyed during the conflict, during the early years of autonomy this challenged the ability of existing courts to function and the ability of the autonomous government to establish courts. As new court infrastructure has developed, the courts have been circuiting more regularly and they have made progress in clearing the backlog, particularly of serious criminal cases. The Office of the Public Solicitor also opened a new office in Bougainville in 2012 to provide legal advice to Bougainvilleans. Illustrating increasing awareness of the courts, there has been a rise in people seeking Interim Protection Orders in cases of violence against women and children.

However, looking only at the police service and courts presents a partial view of the way justice is achieved in Bougainville. During public consultations on the draft constitution, many Bougainvilleans stated that they 'want[ed] to see kastom [custom] built into, and recognised as part of, the justice system' (Bougainville Constitutional Commission 2004, 55). Consequently, the Bougainville police are mandated to strengthen customary authority, respect human rights and develop 'rehabilitatory and reconciliatory concepts of policing. They are also required to 'work in harmony and partnership' with Councils of Elders, Village Assemblies and other traditional leaders 'to resolve disputes and maintain law and order in communities' (ABG Constitution, section 148(2)). Accordingly, the Bougainville Police Service incorporates the Bougainville Community Auxiliary Police Service, which is involved in 'community dispute resolution and peace building practices' as well as 'law and order and conflict prevention' (McGovern and Taga 2009; Dinnen and Peake 2013). The auxiliary police also utilise a 'community-based approach' to policing and work closely with the Council of Elders and traditional leaders to mediate local disputes, encourage reconciliation and prevent the escalation of conflict (interview with an international adviser to the ABG, 31 August 2010; Dinnen and Peake 2013). 
The rule of law is also upheld by a combination of liberal and local justice mechanisms. The most established courts are the Village Courts created by Papua New Guinea law, which operate in most areas and have jurisdiction over any civil dispute arising in that area and over specified criminal matters (Village Courts Act 1973, sections 15, 23 and 25). ${ }^{2}$ While Village Courts are formal institutions, since magistrates are untrained and lawyers do not appear in Village Courts, it is usual for magistrates to utilise a 'creative' mix of formal and customary law (Goddard 2000, 242; Boege 2008; interview with a former member of the ABG, 2 November 2010). Village Courts are said to perform a valuable role, as they are 'readily accessible', 'relatively unbiased' and offer a forum in which the local community 'can witness the righting of wrongs and the reasonable settlement of disputes' (Goddard 2000, 243). Village Courts are also able to provide outcomes that are 'highly contextualised and consequently of considerable local credibility and legitimacy' (Hegarty 2009, 3). However, Village Courts are said to be overworked and under-resourced, ${ }^{3}$ as until the formal justice system becomes well established the Village Courts are being asked to deal with cases that extend well beyond their powers (Bougainville Human Rights Committee 2011).

While these multiple layers of liberal and local mechanisms seek to impose law and order and uphold the rule of law, there is evidence that the provision of amnesties and pardons for crimes that occurred during the conflict has cultivated a culture of impunity as it has 'given the impression to the general population that there is [sic] no consequences for abusing the rights of others' (Bougainville Human Rights Committee 2011), particularly as perpetrators are perceived to have avoided participating (or participating meaningfully) in local reconciliation practices. During public consultations on the new constitution, Bougainvilleans were 'generally supportive' of the amnesty and pardon provisions of the Bougainville Peace Agreement, but there was no consensus on how to otherwise deal with crimes that occurred during the conflict (Bougainville Constitutional Commission 2004, 251). Many Bougainvillean CSOs called for these amnesties to be conditional on a truth and reconciliation process involving 'public recognition of wrong done and forgiveness' (Sister Lorraine Garasu quoted in Howley 2002, 282), which reflects elements of local reconciliation practices. Ordinary Bougainvilleans expressed

2 Including motor vehicle offences, minor assaults, drinking, property damage and disturbing the peace.

3 In 2011, Village Court magistrates were paid K2 per week (less than US\$1). 
mixed views on this proposal; some called for a truth and reconciliation commission to tell 'the story of what happened', others favoured customary reconciliation initiatives that are seen as 'truly grounded in Bougainvillean culture' (Bougainville Constitutional Commission 2004, 252). Bougainvillean constitution-makers expressed less support, with some claiming that it would be 'contrary to custom' and could inhibit the weapons disposal process (Bougainville Constitutional Commission 2004, 114-115). Consequently, the Constitution reiterates the amnesty and pardon provisions of the Bougainville Peace Agreement (ABG Constitution 2004, section 187 and Schedules 6.1 and 6.2), recognises that human rights 'issues' occurred during the crisis and requires the autonomous government to formulate a policy for dealing with them, and for effecting reconciliation that utilises Bougainville 'customs and practices ... so far as is possible' (ABG Constitution 2004, section 187).

Bougainvillean political elites have continued to favour reconciliation guided by local sociopolitical practices in relation to the conflict. However, there are questions over the conduct of many customary reconciliations. While many reconciliations have been 'inclusive affairs' that have 'brought entire communities together', they have often 'failed ... to address the need for truth telling and justice for deeper healing', instead encouraging a 'forgive and forget' approach to past wrongs either because perpetrators were perceived to lack sincerity or because the compensation offered or sanctions imposed were inadequate (Bougainville Human Rights Committee 2011).

Reconciliations have also become increasingly commercialised, with monetary compensation, along with financial support for travel to the reconciliation ceremony and food to conduct the ceremony, often seen as more important than the act of reconciliation itself. Indeed, there is an emerging culture of former combatants seeking compensation from the autonomous government or international donors before they participate in reconciliation ceremonies, which has raised questions about their sincerity and undermined the perceived legitimacy of those ceremonies. There has also been 'no mechanism to ensure compliance' with reparation agreements and other reciprocal arrangements agreed during reconciliation ceremonies (Bougainville Human Rights Committee 2011). When this is combined with the fact that there has been no formal transitional justice mechanism to deal with crimes committed during the crisis, there is some evidence that a culture of impunity has developed with respect to crimes committed since autonomy. As a result, Bougainvilleans are said to be 
'confused as to their rights to pursue justice in individual cases of severe abuse' (Bougainville Human Rights Committee 2011). In the face of this perceived impunity, some families of victims are engaging in increasingly violent forms of 'local justice', including 'horrific tortures and executions' as 'payback', which is also having a detrimental effect on the rule of law (Bougainville Human Rights Committee 2011).

\section{Conclusion}

Therefore, it appears that reconciliation coupled with amnesties and pardons has played a mixed role in the social reconstruction of Bougainville. Governance mechanisms have been established that combine liberal and local sociopolitical practices and appear to be viewed as relatively legitimate, albeit with varying levels of effectiveness. The pursuit of justice has been more mixed, as the pragmatic decision by Bougainvillean elites to favour reconciliation over a formal transitional justice mechanism has contributed to the emergence of a culture of impunity.

As described, some Bougainvillean CSOs have led a push to create a truth and reconciliation commission (interview with a Bougainvillean women's leader, 25 January 2011), noting that crimes and other human rights have been 'hardly talked about and hardly discussed' during the existing reconciliation process (Garasu in Howley 2002, 282). Yet the fact that the amnesty and pardon were enshrined in the Papua New Guinea and Bougainville constitutions means that they are 'obstinate amnesties' (Lessa et al. 2014, 85), which are difficult to wind back, although other cases have illustrated that sufficient momentum can lead to the repeal of such laws. ${ }^{4}$

However, questions have been raised about both these CSOs and their proposals. The increased influence of international CSOs, and their tendency to engage with and fund elite, Bougainvillean CSOs that speak in internationalised language of transitional justice and human rights, may be creating incentives for local CSOs to focus on such proposals. Only a small proportion of Bougainvilleans, mostly from educated, urban backgrounds, belong to such CSOs. Moreover, the individuals involved are often traditional or church leaders, or members of the autonomous government and local-level sociopolitical institutions. Therefore, it is

4 Such as in Argentina. 
unclear whether these CSOs attract support because of this or because of the legitimacy of their proposals (Regan 2003). In addition, proposals to establish a formal transitional justice mechanism have largely failed to gain traction among ordinary Bougainvilleans, and consequently these CSOs have struggled to gain momentum for their proposals. Instead, a distinction may need to be drawn between the views of the primarily urban elites who are involved in CSOs, for whom international donors have created political space to advocate for such a commission, and those of people who are embedded within communities, who have more immediate developmental needs. Indeed, the Bougainville case highlights that, while international CSOs may advocate criminal trials as crucial to social reconstruction, many ordinary people in conflict-affected societies favour mechanisms that allow them to 'reconcile in order to survive' (interview with an international adviser to the ABG, 31 August 2010).

\section{Bibliography}

Afflito, F. M. 2000. 'Victimization, Survival, and the Impunity of Forced Exile: A Case Study from the Rwandan Genocide'. Crime, Law and Social Change 34: 77-97. doi.org/10.1023/A:1008367712285.

Amnesty International. 1990. Papua New Guinea: Human Rights Violations on Bougainville, 1989-1990. London: Amnesty International.

Backer, David. 2003. 'Civil Society and Transitional Justice: Possibilities, Patterns and Prospects'. Journal of Human Rights 2 (3): 297-313. doi.org/10.1080/ 1475483032000132999.

Bakiner, Onur. 2014. 'Truth Commission Impact: An Assessment of How Commissions Influence Politics and Society'. The International Journal of Transitional Justice 8 (1): 6-30. doi.org/10.1093/ijtj/ijt025.

Biggar, Nigel. 2003. 'Making Peace or Doing Justice: Must We Choose?'. In Burying the Past: Making Peace and Doing Justice After Civil Conflict, edited by Nigel Biggar, 3-24. Washington: Georgetown University Press.

Boege, Volker. 2008. A Promising Liaison: Kastom and State in Bougainville. The Australian Centre for Peace and Conflict Studies, Occasional Paper Number 12. Brisbane: University of Queensland.

Boege, Volker. 2009. 'Peacebuilding and State Formation in Post-Conflict Bougainville'. Peace Review 21: 29-37. doi.org/10.1080/10402650802 690037. 
Boege, Volker. 2012. 'Hybrid Forms of Peace and Order on a South Sea Island: Experiences from Bougainville (Papua New Guinea)'. In Hybrid Forms of Peace: From Everyday Agency to Post-Liberalism, edited by Oliver P. Richmond and Audra Mitchell, 65-76. Basingstoke: Palgrave Macmillan.

Boege, Volker. 2013. Bougainville Report, Project: Addressing Legitimacy Issues in Fragile Post-Conflict Situations to Advance Conflict Transformation and Peacebuilding. Brisbane: University of Queensland.

Boege, Volker, Anne Brown and Kevin Clements. 2009. 'Hybrid Political Orders, Not Fragile States'. Peace Review 21: 13-21. doi.org/10.1080/ 10402650802689997.

Boege, Volker and Lorraine Garasu. 2004. 'Papua New Guinea: A Success Story of Postconflict Peacebuilding in Bougainville'. In Searching for Peace in Asia Pacific: An Overview of Conflict Prevention and Peacebuilding Activities, edited by Annelies Heijmans, Nicola Simmonds and Hans van de Veen, 564-580. Boulder and London: Lynne Rienner.

Bougainville Constitutional Commission. 2004. Report of the Bougainville Constitutional Commission: Report on the Third and Final Draft of the Bougainville Constitution. Arawa and Buka: Bougainville Constitutional Commission.

Bougainville Human Rights Committee and Civil Society Bougainvilleans. 2011. Universal Periodic Review: Bougainville Civil Society Stakeholder Shadow Report to OHCHR. Buka: Bougainville Human Rights Committee and Civil Society Bougainvilleans.

Brahm, Eric. 2007. 'Uncovering the Truth: Examining Truth Commission Success and Impact'. International Studies Perspectives 8: 16-35. doi.org/10.1111/ j.1528-3585.2007.00267.x.

Braithwaite, John. 2003. 'Principles of Restorative Justice'. In Restorative Justice and Criminal Justice: Competing or Reconcilable Paradigms?, edited by Andreas von Hirsch, Julian V. Roberts, Anthony E. Bottoms, Kent Roach and Mara Schiff, 1-20. Oxford: Hart Publishing.

Collier, Paul and Anke Hoeffler. 2004. 'Greed and Grievance in Civil War'. Oxford Economic Papers 56: 563-595. doi.org/10.1093/oep/gpf064.

Commonwealth Secretariat and PIF 2005. General Election for the Autonomous Bougainville Government: Report of the Commonwealth-Pacific Islands Forum Expert Team. Suva: Pacific Islands Forum/Commonwealth Secretariat. 
Commonwealth Secretariat and PIFS. 2010. General Election; PIFS, Report of the Pacific Islands Forum Secretariat's Election Observer Team to the 2010 Elections for the Office of President and Members of the House of Representatives of the Autonomous Region of Bougainville. Suva: Pacific Islands Forum.

Dahl, Robert A. 1989. Democracy and Its Critics. New Haven: Yale University Press.

Dinnen, Sinclair and Gordon Peake. 2013. 'More Than Just Policing: Police Reform in Post-Conflict Bougainville'. International Peacekeeping 20 (5): 570-584. doi.org/10.1080/13533312.2013.853961.

Finnroad. 2008. Papua New Guinea - Australia Transport Sector Support Program (TSSP) Supported by the Australian Government - AusAID: Socio-Economic Study - TSSP Provinces, Baseline Report. Helsinki: Finnroad.

Galtung, Johan. 1990. 'Cultural Violence'. Journal of Peace Research 27 (3): 291-305. doi.org/10.1177/0022343390027003005.

Goddard, Michael. 2000. 'Three Urban Village Courts in Papua New Guinea: Comparative Observations on Dispute Settlement'. In Reflections on Violence, edited by Sinclair Dinnen and Alison Ley, 241-253. Canberra: Hawkins Press.

Habermas, J. 1996. Between Facts and Norms: Contributions to a Discourse Theory of Law and Democracy, translated by W. Rehg. Cambridge: MIT Press. doi.org/10.7551/mitpress/1564.001.0001.

Hakena, Helen, Peter Nines and Bert Jenkins, eds. 2006. NGOs and Post-Conflict Recovery: The Leitana Nehan Women's Development Agency, Bougainville. Canberra: ANU E Press. doi.org/10.26530/OAPEN_459395.

Hamber, Brandon and Gráiine Kelly. 2004. A Working Definition of Reconciliation. Belfast: Democratic Dialogue.

Havini, M. T. 1995. A Compilation of Human Rights Abuses against the People of Bougainville 1989-1995, Vol. 1. Sydney: Bougainville Freedom Movement.

Havini, M. T. 1996. A Compilation of Human Rights Abuses against the People of Bougainville 1989-1996, Vol. 2. Sydney: Bougainville Freedom Movement.

Hayner, Priscilla B. 2001. Unspeakable Truths: Facing the Challenges of Truth Commissions. New York: Routledge.

Hegarty, D. 2009. 'Governance at the Local Level in Melanesia - Absent the State'. Commonwealth Journal of Local Governance 3: 1-19. doi.org/10.5130/ cjlg.v0i0.1099. 
Howley, Pat. 2002. Breaking Spears and Mending Hearts: Peacemakers and Restorative Justice in Bougainville. London: Zed Books.

Kim, Hun Joon and Kathryn Sikkink. 2010. 'Explaining the Deterrence Effect of Human Rights Protections for Transitional Countries'. International Studies Quarterly 54: 939-963. doi.org/10.1111/j.1468-2478.2010.00621.x.

Kritz, Neil J. 1996. 'Coming to Terms with Atrocities: A Review of Accountability Mechanisms for Mass Violations of Human Rights'. Law and Contemporary Problems 59 (4): 127-152. doi.org/10.2307/1192195.

Lederach, Paul John. 1997. Building Peace: Sustainable Reconciliation in Divided Societies. Washington DC: U.S. Institute of Peace Press.

Lessa, Francesca, Tricia D. Olsen, Leigh A. Payne, Gabriel Pereira and Andrew G. Reiter. 2014. 'Overcoming Impunity: Pathways to Accountability in Latin America'. The International Journal of Transitional Justice 8 (1): 75-98. doi.org/ 10.1093/ijtj/ijt031.

Long, William J. and Peter Brecke. 2003. War and Reconciliation: Reason and Emotion in Conflict Resolution. Cambridge: MIT Press. doi.org/10.7551/ mitpress/7154.001.0001.

Loveman, Mara. 1998. 'High-Risk Collective Action: Defending Human Rights in Chile, Uruguay, and Argentina'. American Journal of Sociology 104 (2): 477-525. doi.org/10.1086/210045.

Mallinder, Louise. 2007. 'Can Amnesties and International Justice be Reconciled?'. The International Journal of Transitional Justice 1 (2): 208-230. doi.org/10.1093/ijtj/ijm020.

Masono, Raymond. 2006. Government Capacity and Citizen Expectations in Bougainville: The Impact of Political Autonomy. Crawford School of Economics and Government Discussion Paper 06-08. Canberra: The Australian National University.

McEvoy, Kieran. 2007. 'Beyond Legalism: Towards a Thicker Understanding of 'Transitional Justice'. Journal of Law and Society 34 (4): 411-440. doi. org/10.1111/j.1467-6478.2007.00399.x.

McGovern, James and Monica Taga. 2009. Review of the Bougainville Community Police Project (Phase 4): BCCP Review Report. www.aid.govt. nz/about-aid-programme/measuring-results/evaluation/activity-reports/ 2010-review-and-evaluation-reports/bougainville-com (accessed 10 October 2013, site discontinued). 
McSherry, J. P. and Raul Molina Mejia. 1992. 'Confronting the Question of Justice in Guatemala'. Social Justice 19 (3): 1-28.

Molina Mejia, Raul. 1999. 'The Struggle against Impunity in Guatemala'. Social Justice 26 (4): 55-83.

Nisira, Patrick. 2010. Speaking at 'Elections in Bougainville and Solomon Islands', State, Society and Governance in Melanesia Conference, The Australian National University, Canberra, 3 November 2010.

OHCHR (Office of the United Nations High Commissioner for Human Rights). 2006. Rule-of-Law Tools for Post-Conflict States-Amnesties. New York: United Nations.

Olsen, Tricia D., Leigh A. Payne, Andrew G. Reiter and Eric Wiebelhaus-Brahm. 2010. 'When Truth Commissions Improve Human Rights'. The International Journal of Transitional Justice 4 (3): 457-476. doi.org/10.1093/ijtj/ijq021.

Opotow, Susan. 2001. 'Reconciliation in Times of Impunity: Challenges for Social Justice'. Social Justice Research 14 (2): 149-170. doi.org/10.1023/ A: 1012888902705.

Orentlicher, Diane F. 1991. 'Settling Accounts: The Duty to Prosecute Human Rights Violations of a Prior Regime'. Yale Law Journal 100 (8): 2537-2615. doi.org/10.2307/796903.

Paz, Rojas B. 1999. 'Impunity and the Inner History of Life'. Social Justice 26 (4): 13-30.

Penrose, Mary Margaret. 1999. 'Impunity - Inertia, Inaction, and Invalidity: A Literature Review'. Boston University International Law Journal 17: 269-310.

Pham, Phuong and Patrick Vinck. 2007. 'Empirical Research and the Development and Assessment of Transitional Justice Mechanisms'. The International Journal of Transitional Justice 1 (2): 231-248. doi.org/10.1093/ijtj/ijm017.

Philpott, Daniel. 2006. The Politics of Past Evil: Religion, Reconciliation and Transitional Justice. Notre Dame: University of Notre Dame Press.

Rawls, John. 1958. 'Justice as Fairness'. The Philosophical Review 67 (2): 164-194. doi.org/10.2307/2182612.

Regan, Anthony J. 2001. 'Why a Neutral Peace Monitoring Force? The Bougainville Conflict and the Peace Process'. In Without a Gun: Australia's Experiences Monitoring Peace in Bougainville, 1997-2001, edited by Monica Wehner and Donald Denoon, 1-18. Canberra: Pandanus Books. 
Regan, Anthony J. 2003. 'An Outcomes Perspective on Civil Society in Melanesia: Reflections on Experience from Bougainville'. Paper presented at the Fourth Plenary: Governance and Civil Society, State, Society and Governance in Melanesia Project, The Australian National University, Canberra, 1 October 2003.

Regan, Anthony J. 2005. 'Identities among Bougainvilleans'. In Bougainville Before the Conflict, edited by Anthony J. Regan and Helga M. Griffin, 418-446. Canberra: Pandanus Books.

Regan, Anthony J. 2009. 'Bougainville's New Directions: Presidential By-Election, Forming a New Ministry, and First Steps of the New Leadership'. State, Society and Governance in Melanesian Seminar, The Australian National University, Canberra.

Regan, Anthony J. 2010a. Light Intervention: Lessons from Bougainville. Washington: U.S. Institute of Peace Press.

Regan Anthony J. 2010b. Speaking at 'Elections in Bougainville and Solomon Islands', State, Society and Governance in Melanesia Conference, The Australian National University, Canberra, 3 November.

Richmond, Oliver P. 2009. 'Becoming Liberal, Unbecoming Liberalism: Liberal-Local Hybridity via the Everyday as a Response to the Paradoxes of Liberal Peacebuilding'. Journal of Intervention and Statebuilding 3 (3): 324-344. doi.org/10.1080/17502970903086719.

Roht-Arriaza, Naomi. 1996. 'Combating Impunity: Some Thoughts on the Way Forward'. Law and Contemporary Problems 59 (4): 93-102. doi.org/10.2307/ 1192193.

Roht-Arriaza, Naomi. 2006. 'The New Landscape of Transitional Justice'. In Transitional Justice in the Twenty-First Century: Beyond Truth Versus Justice, edited by Naomi Roht-Arriaza and Javier Mariezcurrena, 1-16. Cambridge: Cambridge University Press. doi.org/10.1017/CBO9780511617911.

Sanford, Victoria and Martha Lincoln. 2011. 'Body of Evidence: Feminicide, Local Justice, and Rule of Law in "Peacetime" Guatemala'. In Transitional Justice: Global Mechanisms and Local Realities after Genocide and Mass Violence, edited by Alexander Laban Hinton, 67-93. New Brunswick: Rutgers University Press.

Sasa, C. L. 2013. 'Local Government Accountability in Bougainville’. Masters of Philosophy thesis, Massey University. 
Sikkink, Kathryn and Carrie Booth Walling. 2007. 'The Impact of Human Rights Trials in Latin America'. Journal of Peace Research 44 (4): 427-445. doi.org/10.1177/0022343307078953.

Sirivi, Josephine Tankunanu and Marilyn Taleo Havini, eds. 2004. ... As Mothers of the Land: The birth of the Bougainville Women for Peace and Freedom. Canberra: Pandanus Books.

Tamanaha, B. Z. 2004. On the Rule of Law: History, Politics, Theory. Cambridge: Cambridge University Press. doi.org/10.1017/CBO9780511812378.

Thompson, L., prod. 2002. Breaking Bows and Arrows: Bougainville. Television broadcast, SBS Television Australia, 22 March 2002.

Thoms, Oskar N. T., James Ron and Roland Paris. 2010. 'State-Level Effects of Transitional Justice: What Do We Know?. The International Journal of Transitional Justice 4 (3): 329-354. doi.org/10.1093/ijtj/ijq012.

United Nations General Assembly 2005. Basic Principles and Guidelines on the Right to a Remedy and Reparation for Victims of Gross Violations of International Human Rights Law and Serious Violations of International Humanitarian Law. UN Doc. A/RES/60/147 (16 November 2005).

Wallis, Joanne. 2014. Constitution Making during State Building. New York: Cambridge University Press. doi.org/10.1017/CBO9781107587700.

Weah, Aaron. 2012. 'Hopes and Uncertainties: Liberia's Journey to End Impunity'. The International Journal of Transitional Justice 6 (2): 331-343. doi.org/10.1093/ijtj/ijs007.

Weinstein, Harvey M. 2011. 'Editorial Note: The Myth of Closure, the Illusion of Reconciliation: Final Thoughts on Five Years as Co-Editor-in-Chief'. The International Journal of Transitional Justice 5 (1): 1-10. doi.org/10.1093/ ijtj/ijr002. 
This text is taken from Civil Society and Transitional Justice in Asia and the Pacific, edited by Lia Kent, Joanne Wallis and Claire Cronin, published 2019 by ANU Press, The Australian National University,

Canberra, Australia.

doi.org/10.22459/CSTJAP.2019.07 